\title{
DOI 10.26886/2523-6946.1(2)2018.1
}

UDC 616-001.4-039.22

METHOD OF MEASUREMENT OF THE AREA OF SKIN DEFECTS

IN THEIR DIAGNOSTIC AND TREATMENT.

\section{Yaroslav Zarutskiy, MD, PhD, DSc, Professor,}

Serhii Korol PhD,

\section{Kostiantyn Karpenko}

Ukrainian Military Medical Academy, Ukraine, Kyiv

An article is dedicated to modern methods of measuring of defects of the skin. It is considered in it typical methods for determining of the area of a wound or a skin defect, which doctors are using in practice. Attention is paid to both of their advantages and disadvantages, highlighted reasons which are hindering implementation of digital evaluation methods for diagnostic and treatment in wide physician's practice. The authors of the article are based on the analyzed disadvantages of the modern digital methods for evaluation of the area of skin's defect suggest using a photoplanimetric measuring method using a camera, a millimeter-graded lath and a free computer program for the study of medical biology images. The method can be used in many areas of a medical practice: dermatology, septic, vascular, plastic and reconstructive surgery, in the treatment and diagnosis of diseases of any lesions of the skin. As a result of using of the proposed method, the objectivity of the received data increases, the possibility of infection and traumatization of the skin defect is significantly reduced, and a dynamic analysis of treatment is allowed. The availability of tools for measurement, simplicity, objectivity, atraumatic and safety of this method creates the basis for its widespread introduction into the clinical practice of a physician in diagnostics and treatment of skin defects.

Keywords: area measurement, wound, skin defect, diagnostics, evaluation, photo-planimetry, modern methods, photo analysis. 
Я. Л. Заруцький, доктор медичних наук, профрессор; С. О. Король, кандидат медичних наук; К. К. Карпенко. Метод вимірювання площі дефректів шкіри при їх діагностиці та лікуванні / Українська військовомедична академія, Україна, Київ.

Стаття присвячена сучасним способам вимірювання дефректів шкірного покриву. В ній оглянуті типові методи визначення площі рани або дефекту шкіри, які використовують лікарі в практичній діяльності. Увага приділена як перевагам так і їх недолікам, висвітлені причини, що заважають впровадженню цифрових методів оцінки діагностики та лікування в широкій практиці лікаря. Автори статmі на основі проаналізованих недоліків сучасних цифрових методів оцінки площі дефекту шкіри пропонують застосовувати фото планіметричний спосіб вимірювання 3 використанням фотоапарату, міліметр-градуйованої планки та безкоштовної комп'ютерної програми для вивчення медико-біологічних зображень. Спосіб може бути використаним у багатьох сфрерах медичної практики: дерматології, гнійній, судинній, пластичній та реконструктивній хіруреії, при лікуванні та діагностиці захворювань будь-яких уражень шкірного покриву. У результаті використання запропонованого способу підвищується об'єктивність отриманих даних, значно знижується можливість інфрікування та травматизації дефекту шкіри, дозволяється проводити динамічний аналіз лікування. Доступність засобів для вимірювання, простота, об'єктивність, атравматичність і безпечність даного способу створюють підгрунтя для його широкого впровадження в клінічну практику лікаря при діагностиці та лікуванні дефектів шкіри.

Ключові слова: вимірювання площі, рана, дефрект шкіри, діагностика, оцінювання, фото планіметрія, сучасні способи, аналіз фотознімків. 
Вступ. Під час лікування пацієнтів з ураженням (дефектом) шкірного покриву будь-якого походження виникає необхідність визначення площі дефекту шкіри, контролю динаміки лікування або зміни дефекту, так само як і при експериментальному аналізі ефрективності різної терапії ран, виразок або термічних ушкоджень.

Лікарі різних спеціальностей, які займаються лікуванням дефектів шкіри постійно вирішують завдання, пов'язані з визначенням розміру площі десректів та контролем змін ураженої ділянки шкіри, при чому досить часто після встановлення діагнозу подальша оцінка лікування проводиться емпіричним шляхом і може спричинити помилки в інтерпретації ефрективності лікування, хоча об'єктивне оцінювання зміни площі уражених шкірних покривів в процесі лікування дозволяє корегувати проведену терапію. 3 впровадженням в майбутньому електронної історії хвороби пацієнта в документообіг, неминуче постане питання достовірності даних та правильності їх оцінки, особливо при юридичному оцінюванні лікування.

Травматичні дефекти шкіри - одна з найпоширеніших проблем що спостерігається та вирішується в Департаменті надзвичайних ситуацій Сполучених Штатів Америки, частота візитів до закладів охорони здоров'я з цього приводу щороку становить приблизно 11 мільйонів [6].

Повільно заживаюча рана може гоїтися кілька років, або взагалі не гоїтися. Ці рани викликають у хворих хронічний емоційний стрес і $\epsilon$ важкою ношею як для пацієнта, так і для системи охорони здоров'я [1].

Оскільки пацієнти та лікарі хочуть однакових результатів щодо уникнення інфекції та естетичності ранового лікування, сучасний і науковий підхід при лікуванні ран знижує ризики терапії і підвищує задоволеність результатами лікування у пацієнта [7]. 
За результатами дослідження, що проводилося в регіоні Квун Тонг, КНР, з'ясувалося, що близько 24\% пацієнтів, отримують лікування 3 приводу ран. Серед них 70\% - з приводу хронічних ран [2].

Результати отримані Центром ортопедичних досліджень та освіти в Сан-Дієго, США, показують наявність пропорційного взаємозв'язку між одномірними периметрами та вимірами площі, які точно співвідносяться з процесом загоєння рани [4].

Найбільш поширеними є планіметричний метод визначення площі поверхні Л. Н. Попової (1942р.). Недоліками даного способу є його неточність та залежність від ступеню градації кальки, на яку переносяться контури дефекту шкіри, необхідність проведення самостійних розрахунків площі, суб'єктивність, необхідність фрізичного контакту з ураженими ділянками шкіри при перенесенні контурів, можливість травмування та інфрікування дефекту шкіри при його окресленні.

За допомогою цифрового аналізу можливо значно підвищити точність вимірювання площі рани.

Сьогодні $€$ багато комп'ютерних програм, які доступні для визначення площі поверхні рани, легкі у використанні та мають високу точність обчислення $[5,8]$.

Однак, цифрові способи вимірювання площі ран не $є$ дуже поширеними. Труднощі, пов'язані 3 фоотометричною планіметрією $€$ результатом використання фотографії (наприклад, кривизна або кутові відхилення), не властиві "комп'ютерній планіметрії"[3].

Мета. Розробка простого у використанні безконтактного методу визначення площі уражених ділянок шкіри та комп'ютерного обчислення отриманих даних. Застосування методу для об'єктивної оцінки та контролю динаміки хвороби, особливо при тривалому лікуванні дефектів шкіри. 
Сучасними цифровими методами вимірювання $є$ програми для обчислення площі полігонів, реалізовані на основі алгоритму Darex Rex Finley, з недоліками перемінної відстані дефекту шкіри до об’єктиву та зміною масштабу зображення в перспективі при зміні кута фотографування. Також наявні різноманітні програми що використовується для вимірювання площі за допомогою смартфону, недоліками яких $€$ необхідність фотографрування об'єкту на малій відстані, що обмежує вимірювання великих площин, використання спеціальної підставки під смартфон, необхідність аналізу фотознімку на ізольованому фоні, наявність Інтернет підключення для нормальної роботи додатку, непрактичність при використанні в медичній сфері 3 огляду на різноманітність дефектів шкіри (ран).

Задачею запропонованого методу $є$ створення моделі способу комп'ютерного розрахунку ураженої ділянки шкіри за допомогою аналізу фотознімків. Спосіб при цьому є безпечним, швидким і простим у виконанні, адже не потребує прямого контакту вимірювального пристрою з поверхнею дефекту шкіри.

Результати та їх обговорення. Розроблений спосіб характеризується доволі швидким виконанням та об'єктивним комп'ютерним оцінюванням: на отримання зображення витрачається приблизно 15-20 секунд, на комп'ютерну обробку та обчислення цифрового фотознімку в програмі "ImageJ" - не більше двох хвилин.

Спосіб виконується таким чином: положення пацієнта - довільне. Вимірювальну частину міліметр-градуйованої виносної рамки, фріксованої до фотоапарату двома металевими стержнями на постійній відстані від об'єктива та в паралельній йому площині, прикладають під прямим кутом до здорової шкіри поруч з патологічною ділянкою, проводять фоотозйомку. За допомогою програми «ImageJ» на отриманих фротознімках задають референтні значення відстані, 
відповідно до поділок вимірювальної частини виносної рамки та окреслюють площу ураження. Автоматично проводять розрахунки площі поверхні дефекту шкіри. Отримують точні дані.

Для отримання зображень достатньо вимірювальну частину міліметр-градуйованої виносної рамки прикласти до здорових тканин поруч з дефектом шкіри та зробити фотознімок, завдяки чому значно знижуються ризики щодо травмування або інфікування ранової поверхні або патологічно змінених ділянок шкіри.

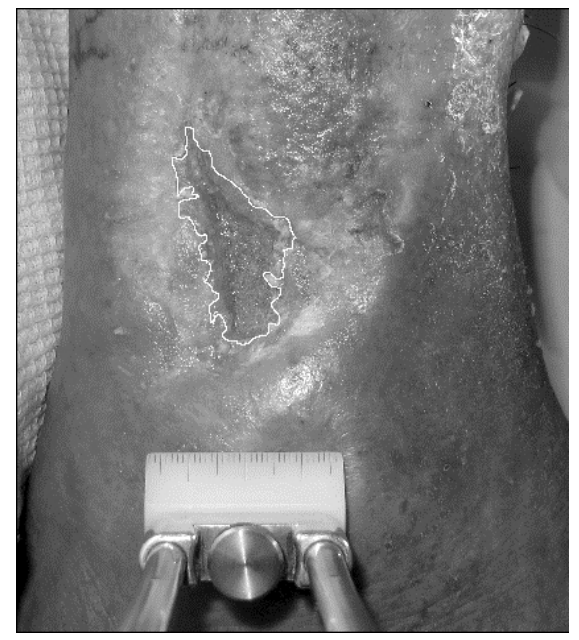

Рис. 1. Представлена методика запропонованого способу: вимірювання площі дефекту шкіри передньої поверхні правої гомілки. Площа трофічної виразки окреслена безперервною білою лінією. Міліметр - градуйована рамка дозволяє задати в комп'ютерній програмі еталонну відстань в один міліметр, пристрій розміщений поруч 3 патологічною ділянкою шкіри та контактує лише зі здоровими тканинами.

Сама градуйована вимірювальна рамка прикріплюється до штативного гнізда фотоапарату, що дозволяє швидко та просто фіксувати патологічні зміни, постійно зберігаючи необхідну відстань та прямий кут при фотографуванні дефекту шкіри.

Аналіз отриманих зображень здійснюється за допомогою програми для вивчення медико-біологічних зображень “ImageJ" - програмою 3 відкритим вихідним кодом для аналізу та обробки зображень. Розроблена співробітниками Національного інституту охорони здоров'я 
(англ. National Institutes of Health) - агентства Департаменту охорони здоров'я США, і розповсюджується без ліцензійних обмежень як суспільне надбання.

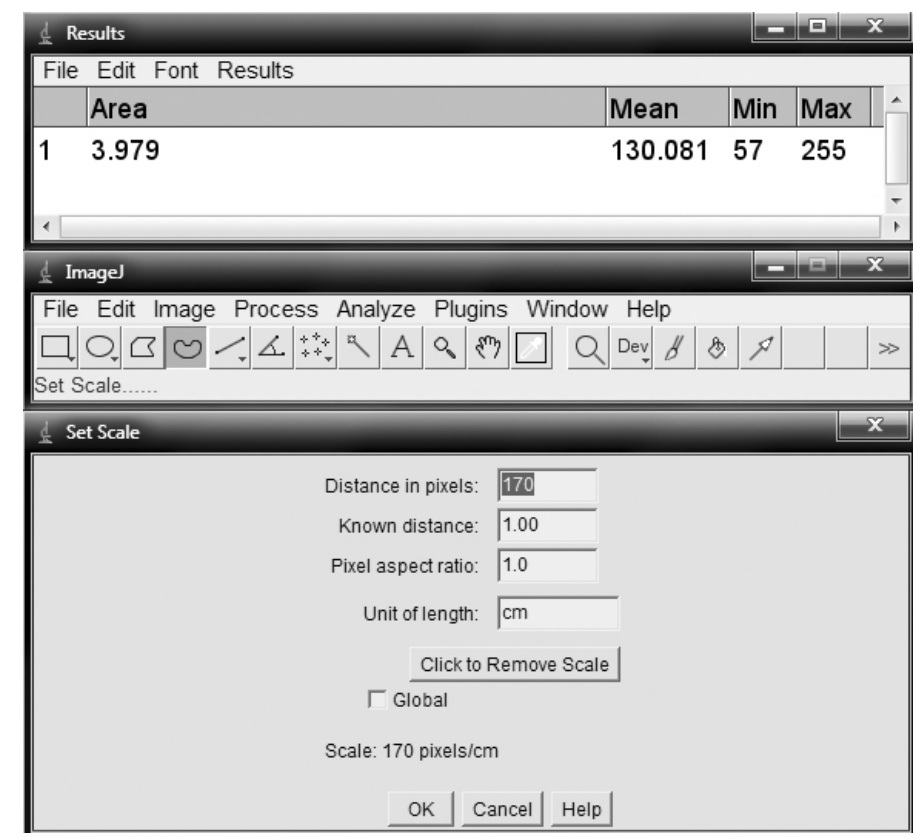

Рис. 2. Відображено інтерфейс програми та результати дослідження дефекту шкіри передньої поверхні правої гомілки, які можна зберігати та порівнювати в динаміці лікування з новими фотознімками патологічної ділянки. Обчислення окресленого дефекту шкіри представлене у вікні "Results" під значенням “Area” та складає 3,97 см²

Відмінною особливістю способу $є$ просте та швидке отримання даних щодо площі ураження без контакту з патологічними ділянками шкіри, комп'ютерний розрахунок площі та його об'єктивність.

Висновки. Доступність засобів для проведення вимірювання та обчислення, простота, ефективність, атравматичність, безпечність та об'єктивність при діагностиці та лікуванні дефектів шкіри із застосуванням запропонованої методики створюють підґрунтя для широкого впровадження даного способу в практичну роботу лікарів різних спеціальностей: дерматологів, хірургів, косметологів та ін.

תimepamypa: 
1. Augustin M., Maier K. (2003). Psychosomatic aspects of chronic wounds. Dermatology and Psychosomatics, 4, 5-13

2. Wong I., Lee D. (2008). Chronic wounds: why some heal and others don't? Psychosocial determinants of wound healing in older people. Hong Kong Journal of. Dermatology and. Venereolog, 16, 71-76

3. Flanagan M., (2003). Improving Accuracy of Wound Measurement in Clinical Practice. Ostomy Wound Manage. 49, 28-40.

4. Cardinal M., Eisenbud D., Armstrong D., (2009). Wound shape geometry measurements correlate to eventual wound healing. Wound Repair and Regen 17, 173-178

5. Plassman P., Peters M., (2001). Recording wound care effectiveness. Journal of Tissue Viability, 12, 24-28.

6. DeBoard R., Rondeau D., Kang C., Sabbaj A., McManus J., (2007). Principles of Basic Wound Evaluation and Management in the Emergency Department. Emergency Medicine Clinics of North America, 25, 23-39

7. Singer A., Mach C., Thode H., (2000). Patient priorities with traumatic lacerations, American Journal of Emergency Medicine,18, 6.

8. Taylor R. (1999) An aid to wound measurement using a computer. Journal of Wound Care, 6, 123-126. 